日薬理誌 (Folia pharmacol. japon.) 68, 167 178 (1972)

\title{
細胞膜機能に関する研 究
}

第 4 報 正常ならびに $\mathrm{CCl}_{4}$ 適用白鶃肝細胞膜 $\mathrm{NADH}-$

cytochrome c reductase の酵素化学的検索

増田 康輔, 口井 正人, 山本 博之

(和歌山県立医科大学蒋理学教室)

(昭和46年 9 月11日受付[特])

私達は既に前報 ${ }^{(-3)}$ に拈いて, 白閶肝細胞膜の NADH-cytochrome c reductase (NADH-cyt. c red. と略 記) 活性が $\mathrm{CCl}$ ，投与後 mitochondria (mit. と略記) 並びに microsome (mic. と略記) のそれ等の活性に ほとんど影響が現われないのにかかわらず極めて早期に著しく上昇し, その経時的变動像には明確な性差が認め られると共に, その活性消長は本䤃素の血墏中への逸脱経過と密接な相関性を示寸事, 更にまた細胞膜系か $\mathrm{CCl}_{4}$ 肝障寒発現の初期の場である可能性を指摘した。しかして本現象は細胞膜分離操作過程に他の細胞内分屏が物理 的に混入し，外観的に該䤃素活性の上昇と見誤まられたのではない事実す判明したが，本現象がいかなる原因に

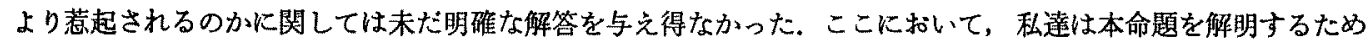
には先ず細胞膜の NADH-cyt. c red. の酵素化学的性格並びにその補醉素の消長をあらかじめ熟知しておく必 要があると考えこれに $2 ， 3$ 検討を加えて見たのでその成鈢を報告する.

\section{実験方法ならびに材料}

実験に供した動物は全て前報"に記载したごとく日本ラットのドンリこウS亲崔性白鼠であり，その飼育条 件，選別等は同様であった。

$\mathrm{CCl}$ 、はオリーブ油に溶解した後, 特記しない限り $0.1 \mathrm{ml} / \mathrm{kg}$ （第 1 報では $0.2 \mathrm{ml} / \mathrm{kg}$ )を腹腔内に投与し6 後に対照群と併行して実験に用いた.

肝細胞膜，mit. 及び mic. の分離は，全て第 1 報”に記载した方法に従った。ただし，スペクトル测定に 用いる場合には，微量の吸着へモグロビンあるいは cytochrome c を除去するため，精製細胞膜標本を0.15 M KCL 溶液で 3 回洗湺した。 また mic.は $\mathrm{KCl}$ 法により採取したものを用いた.

NADH-cyt. c red., NADH-ferricyanide dehydrogenase 及び ATP-ase 活性の測定は前報" の方法に従っ た. NADH-cytochrome $b_{5}$ reductase 活性測定は, 反応液組成 NADH $7.7 \times 10^{-5} \mathrm{M}$, cytochrome $b_{5} 5 \times 10^{-5} \mathrm{M}$, Tris-Acetate 涭衝液 $5 \times 10^{-2} \mathrm{M}(\mathrm{pH} 8.1)$ 亿䣼素蛋白 $0.05 \mathrm{mg}$ を添加することにより反応を開始させ，556 $\mathrm{m} \mu$ で吸光度变化を自記させた。 反応温度は $25^{\circ} \mathrm{C}$ とし, 全量 $1 \mathrm{ml}$ 中で反応させた. 活性値算出に当っては初 速度を用い，556 $\mathrm{m} \mu$ に拉ける cytochrome $b_{5}$ の酸化邊元分子吸光保数 $21 \times 10^{3} \mathrm{~cm}^{-1} \mathrm{M}^{-1}$ から蛋白 $1 \mathrm{mg}$ 当り 1 分間に還元される cytochrome $b_{5} の \mu$ モ儿数でもって活性值を現放した.

NADH-cyt. c red. 及び NADH-ferricyanide dehydrogenase の Km 值測定に当っては電子受容体として の cytochrome c 及び ferricyanide の濃度は一定に保ち NADH の濃度を段階的に变化させ, 常法に従って反 応速度を求め, Lineweaver-Burk のplot をとることにより $\mathrm{Km}$ 值及び Vmax 值を算出した.

差スペクトル" は島津製マルチパーパス分光度計 MPS-50を用いて光路 $1 \mathrm{~cm}$ のセルにて描画させた。 寸

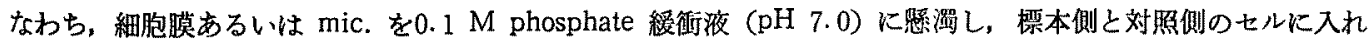
基線を描かせた後，標本側に種々の物質を添加し，スペクトルを描画させ，基線を差引いたスペクトルを差スぺ クトルとした。

cytochrome $b_{5}$ 及び p-450の定量は大村等5) の方法に従い, cytochrome $b_{5}$ は NADH による酸化兾 元差 スベクトルから $424 \mathrm{~m} \mu$ と $409 \mathrm{~m} \mu$ の間の分子吰光係数 $185 \mathrm{~cm}^{-1} \mathrm{M}^{-1}$ を用いてその量を算出し, $\mathrm{p}-450$ は dithi- 


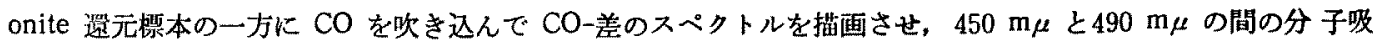
光係数を91 $\mathrm{cm}^{-1} \mathrm{M}^{-1}$ として定量した。

な拉, cytochrome $b_{5}$ は大阪大学医学部生化学漖空の好意により分与されたものを透析処理により硫安を除 いた後使用した。その他の試薬類は全て市扳特級品を用いた。

\section{実 験 成 績}

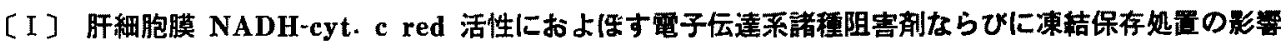

一般に細胞内の電子伝達系酵素は非特異的あるい恃罢的な阻害剤により阻害をらける。そこで細胞膜系に おける NADH-cyt. c red. が細胞内他分局のそれと較べいかなる性質を持つかを阻害放の面から検討してみた。

mit. あるいは mic. の電子伝達系醭には flavoprotein として SH-酵素が含まれていることが知られてい るがの゙), 細胞膜の NADH-cyt. c red. は非特異的な SH 基阻害剂である P-chloromercuric benzoate (PCM

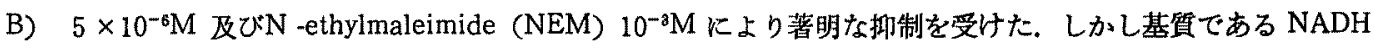
$2 \times 10^{-8} \mathrm{M}$ の共存下では活性阻害は完全に防御された。たたし PCMBであらかじめ阻害效果を発惓せしめた後

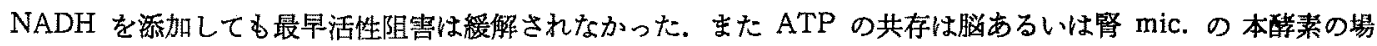

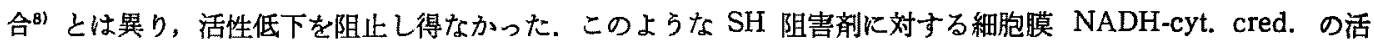
性低下は， $\mathrm{CCl}_{4}$ 適用群についても同様に認められた（Table 1)．従って細胞膜の本酵素は $\mathrm{SH}$ 酵素である と思われる。

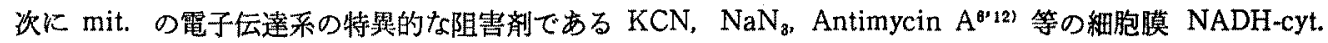
c red. に及ぼす影響を検討したところ，細胞膜の該酻素活性は（ $\mathrm{CCl}_{4}$ 適用の有無にかかからず）これら阻㕩 润により抑制を受けない事がわかった（Fig，1），に彷って䋎胞膜の本酥素は mit.より mic. に近い性格を

Table 1. Protecton of NADH against NADH-cytochrome $c$ reductase inhibition induced by p-chloromercuric benzoate or N-ethylmaleimide.

\begin{tabular}{|c|c|c|c|c|}
\hline \multicolumn{2}{|c|}{ Addition (M) } & Preincub. $\left(25^{\circ} \mathrm{C}\right)$ & \multicolumn{2}{|c|}{ Activity } \\
\hline \multicolumn{2}{|c|}{-} & Omin. & 0.089 & 0.330 \\
\hline \multicolumn{2}{|c|}{-} & 10 & 0.077 & \\
\hline РCMB & $\begin{array}{l}2 \times 10^{-6} \\
5 \times 10^{-6}\end{array}$ & $\begin{array}{l}10 \\
10\end{array}$ & $\begin{array}{l}0.055 \\
0.031\end{array}$ & 0.011 \\
\hline $\mathrm{NADH}$ & $2 \times 10^{-3}$ & 10 & 0.091 & 0.338 \\
\hline $\begin{array}{l}\text { PCMB } \\
\text { NADH }\end{array}$ & $\begin{array}{l}5 \times 10^{-6} \\
2 \times 10^{-3}\end{array}$ & 10 & 0.083 & 0.227 \\
\hline ATP & $3 \times 10^{-3}$ & 10 & 0.090 & 0.300 \\
\hline $\begin{array}{l}\text { PCMB } \\
\text { ATP }\end{array}$ & $\begin{array}{l}5 \times 10^{-6} \\
3 \times 10^{-3}\end{array}$ & 10 & 0.053 & 0.001 \\
\hline $\begin{array}{l}\text { NADH } \\
\text { ATP }\end{array}$ & $\begin{array}{l}2 \times 10^{-3} \\
3 \times 10^{-3}\end{array}$ & 10 & 0.078 & \\
\hline $\begin{array}{l}\text { PCMB } \\
\text { ATP } \\
\text { NADH }\end{array}$ & $\begin{array}{l}5 \times 10^{-6} \\
3 \times 10^{-3} \\
2 \times 10^{-3}\end{array}$ & 10 & 0.073 & \\
\hline $\begin{array}{l}\text { PCMB } \\
\text { NADH }\end{array}$ & $\begin{array}{l}5 \times 10^{-6} \\
2 \times 10^{-3}\end{array}$ & $\begin{array}{l}10 \\
+10\end{array}$ & 0.038 & \\
\hline \multirow[t]{2}{*}{$\mathrm{NEM}$} & $10^{-4}$ & 10 & 0.092 & \\
\hline & $10^{-3}$ & 10 & 0.017 & \\
\hline $\begin{array}{l}\text { NEM } \\
\text { NADH }\end{array}$ & $2 \times 10^{10^{-3}}$ & 10 & 0.082 & \\
\hline
\end{tabular}

Activities are expressed as $\mu$ moles of cyt. c reduced $/ \mathrm{mg}$ protein $/ \mathrm{min}$. 


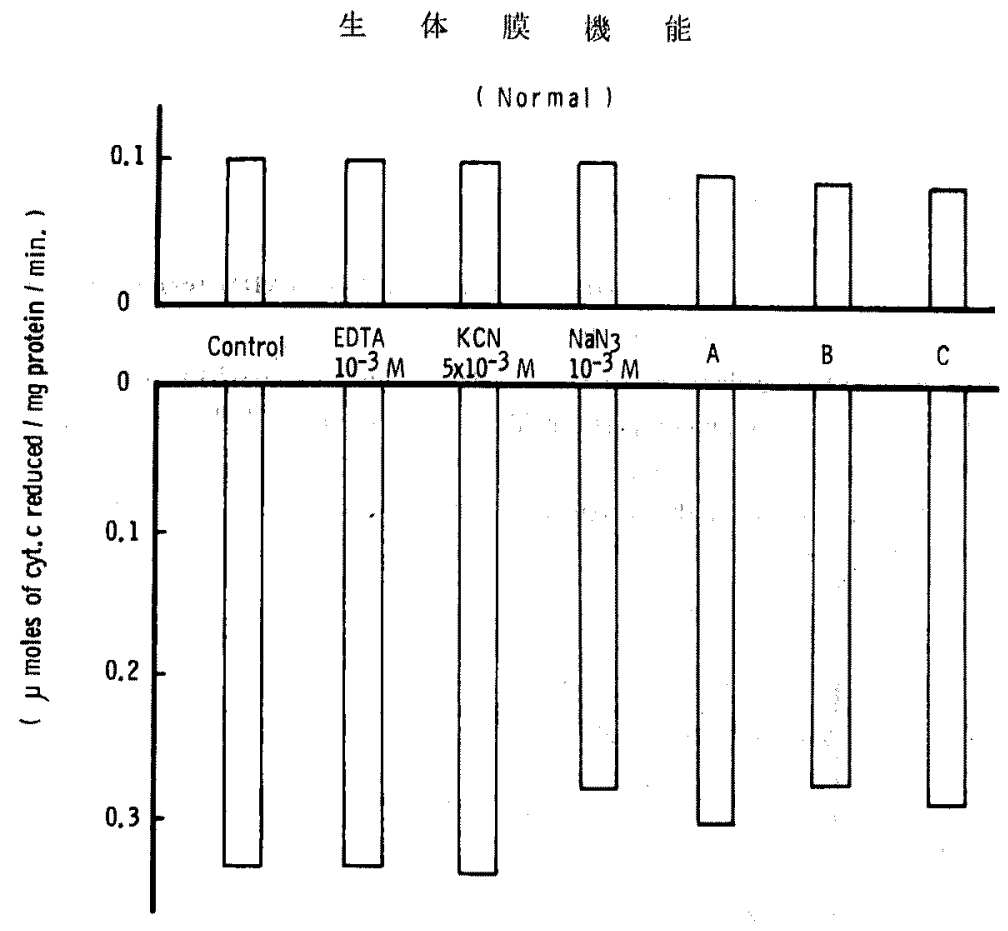

$\left(\mathrm{C} \mathrm{Cl}_{4}\right)$

$$
\begin{aligned}
& \text { A : Antimycin A } 3 \times 10^{-6} \mathrm{M} \\
& B: \text { o-Phenanthroline } 10^{-3} \mathrm{M} \\
& \text { C : a, a-Dipyridyl } 10^{-3} \mathrm{M}
\end{aligned}
$$

Fig. 1. Effects of various inhibitors added on NADH-cytochrome $c$ reductase activity in liver cell membrane obtained from female rats treated with $\mathrm{CCl}_{4}$ or none.

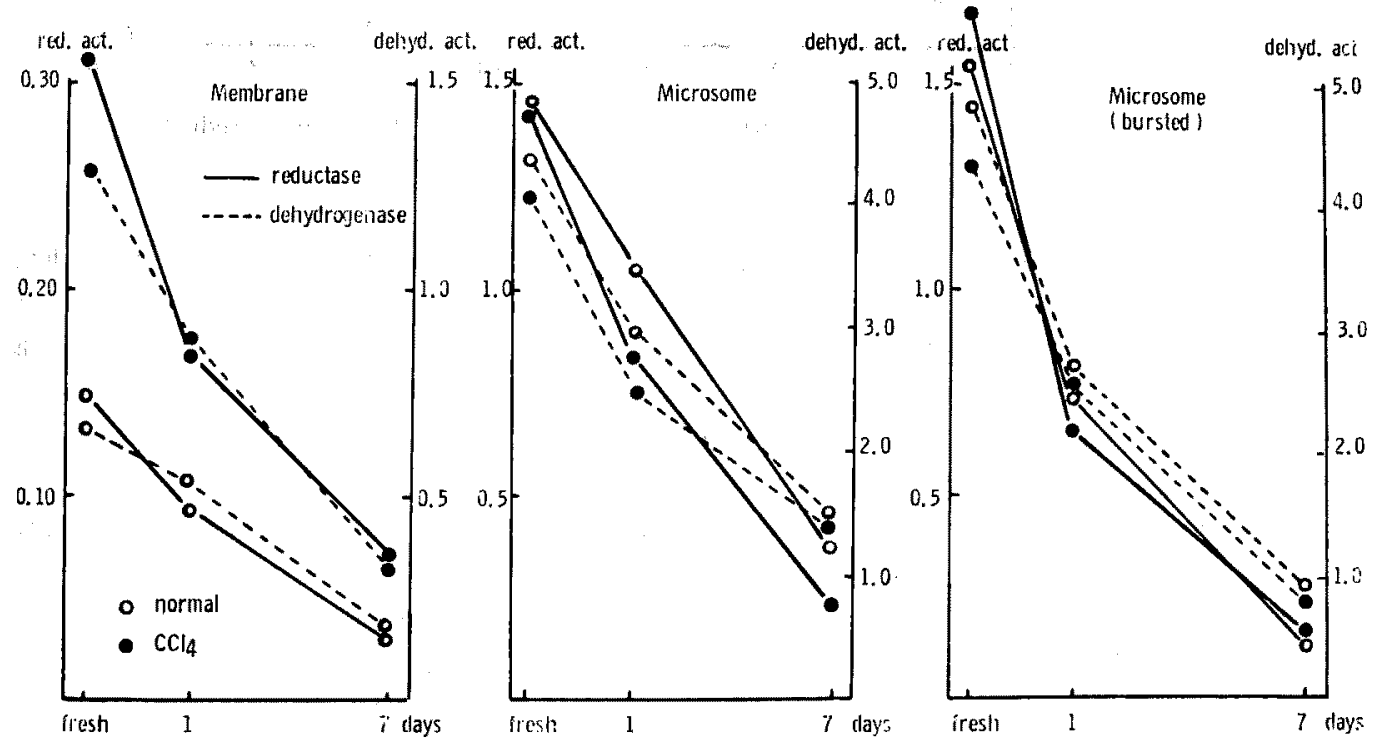

Fig. 2. Loss of NADH-cytochrome c reductase and NADH-ferricyanide dehydrogenase activities in plasma membranes and microsomes from rat liver by storing at $-20^{\circ} \mathrm{C}$. (Protein concentration: $1.0 \mathrm{mg} / \mathrm{ml}$ in $20 \mathrm{mM}$ Tris-acetate buffer $\mathrm{pH} 8.1$ ) 
持つものと思われる.

他面，予优实験として細胞膜並びに mic。の NADH-cyt. c red.及びその flavoprotein level での活性を示 す NADH-ferricyanide dehydrogenase の凍結保存による活性低下を調べてみた。 得られた結果は Fig. 2 に示 すごとく細胞膜，mic. 共に $\mathrm{CCl}_{4}$ 適用に関係なく、これら䣼菜活性值の低下には有意な差は認められなかった.

II 肝細胞膜ならびに mic. における NADH-cyt. c red. および NADH-ferricyanie dehydrogenase の $\mathrm{Km}$ おび $\mathrm{V}_{\max }$ 值にむよばす $\mathrm{CCl}_{4}$ 適用 $\left(6^{\mathrm{h}}\right)$ の影翌

更に本醉素系について， $\mathrm{CCl}_{4}$ 適用の有無による細胞膜並びに mic. の NADH-cyt. c red. 及び flavoprotein level の NADH-ferricyanide dehydrogenase 活性の性格を知る目的で両醳素と基質との吸着性すなわち $\mathrm{Km}$ 值 を Lineweaver-Burk の plot から調べてみた.

Fig. 3に示したごとく, reductase, dehydrogenase 共に, $\mathrm{CCl}_{4}$ 投与の有無にかかからず細胞膜と mic.は 略々同一 Km 值を示した。

(NADH Cyt. $c$ reduclase)

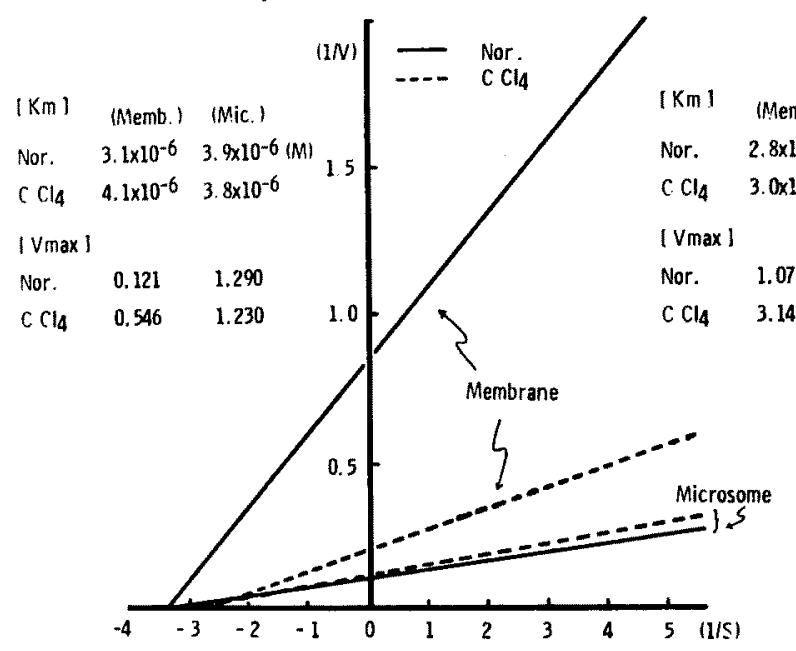

(NADH-ferricyanide dehydrogenase)

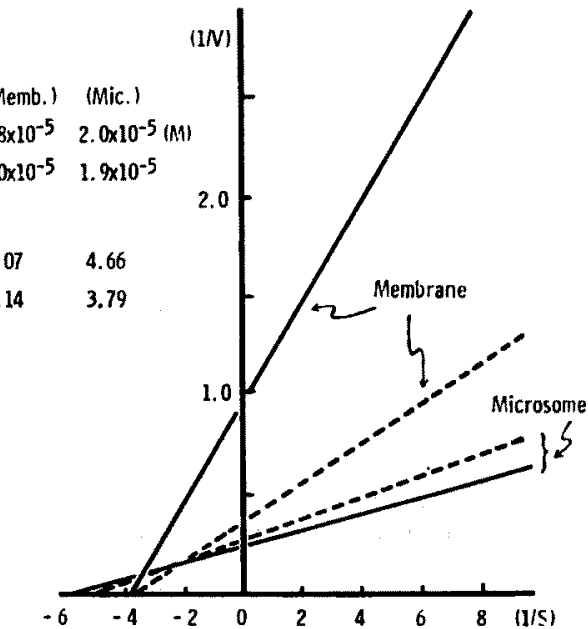

Fig. 3. Lineweaver-Burk plots of initial rates of both NADH-cytochrome $c$ reductase and $\mathrm{NADH}$-ferricyanide dehydrogenase of either plasma membranes or microsomes from female rat liver.

しかし，Vmax 值は mic. の方が圧倒的に高く，また細胞膜の $\mathrm{V} \max$ 值は $\mathrm{CCl}_{4}$ 投与に上り両酵素系共に 上算した。

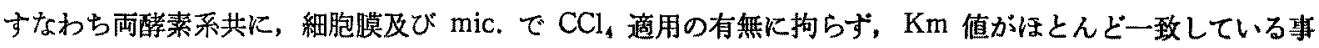
から，またすでに述べたごとく阻害剤に対する結果からも細胞膜における両醅素は mic. のものと同一 origin であり，細胞膜の NADH-cyt. c red. 系は mic. と同様な flavoprotein 及び cytochrome $b_{5}$ を释る電子伝達 系路ではないかと思われる.

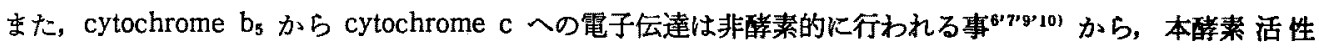
の上昇は flavoprotein 及び cytochrome $b_{5}$ の增加に由来する可能性があり，従って $\mathrm{CCl}_{4}$ 適用により惹爬され る細胞膜 NADH-cyt. c red. 及び NADH-ferricyanide dehydrogenase 活性の上昇は, 酵素誘導によるかある いは mic. からの酵素及び cofactor の移動によるのではないかと予想される．しかしながら私達の別報”に拉 ける成績から, 上述醳素活性の上开は誘導に起因寸るとは考学難い，そこで私達は後者による可能性，すなわら mic. からの dehydrogenase 並びに補醭である cytochrome $b_{5}$ の移動の結果ではないかと推定し以下述 い る様な検討を加党て見た。 


\section{〔III〕肝細胞膜における cytochrome bs および $\mathbf{P}-450$ の同定}

a) mit. 並びに mic. の酸化還元に関寸る予整的観察：

先ず，予储実験として mit. 及び mic. のへム蛋白について検討したところ, mit. ではFig. 4 A に示す ごとく姆気的条件下で NADH 及び Succinate の添加により著明な美スペクトルが現われ，cytochrome b, c,

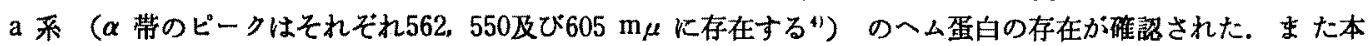
パターンは dithionite 添加でる同様な結果が得られる.この際, mit. の電子伝達系の cytochrome b〜c 間の電 子伝達を阻害する antimycin A を添加すると cytochrome c, a の峰が消失L cytochrome b の峰のみが残存し た. しかして flavoprotein level の阻害珮である rotenone ${ }^{12)}$ の添加は, cytochrome b の峰をる消失せしめた (Fig. 4B).

次に Fig. 5 に示す通り mic. に NADH 添加ないし更に還元型に $\mathrm{CO}$ 処理を行らとそれぞれ cytochrome bs 及び p-450 のスペクトルが現われた. (cytochrome bs は424 $\mathrm{m} \mu$ 及び556 $\mathrm{m} \mu$ K，また p-450は 450 $\mathrm{m} \mu$ K特異的な峰を示す）次に mic. に dexycholate 妈理を施すと450 $\mathrm{m} \mu$ の峰は420 $\mathrm{m} \mu$ に移動し，いわ

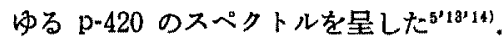
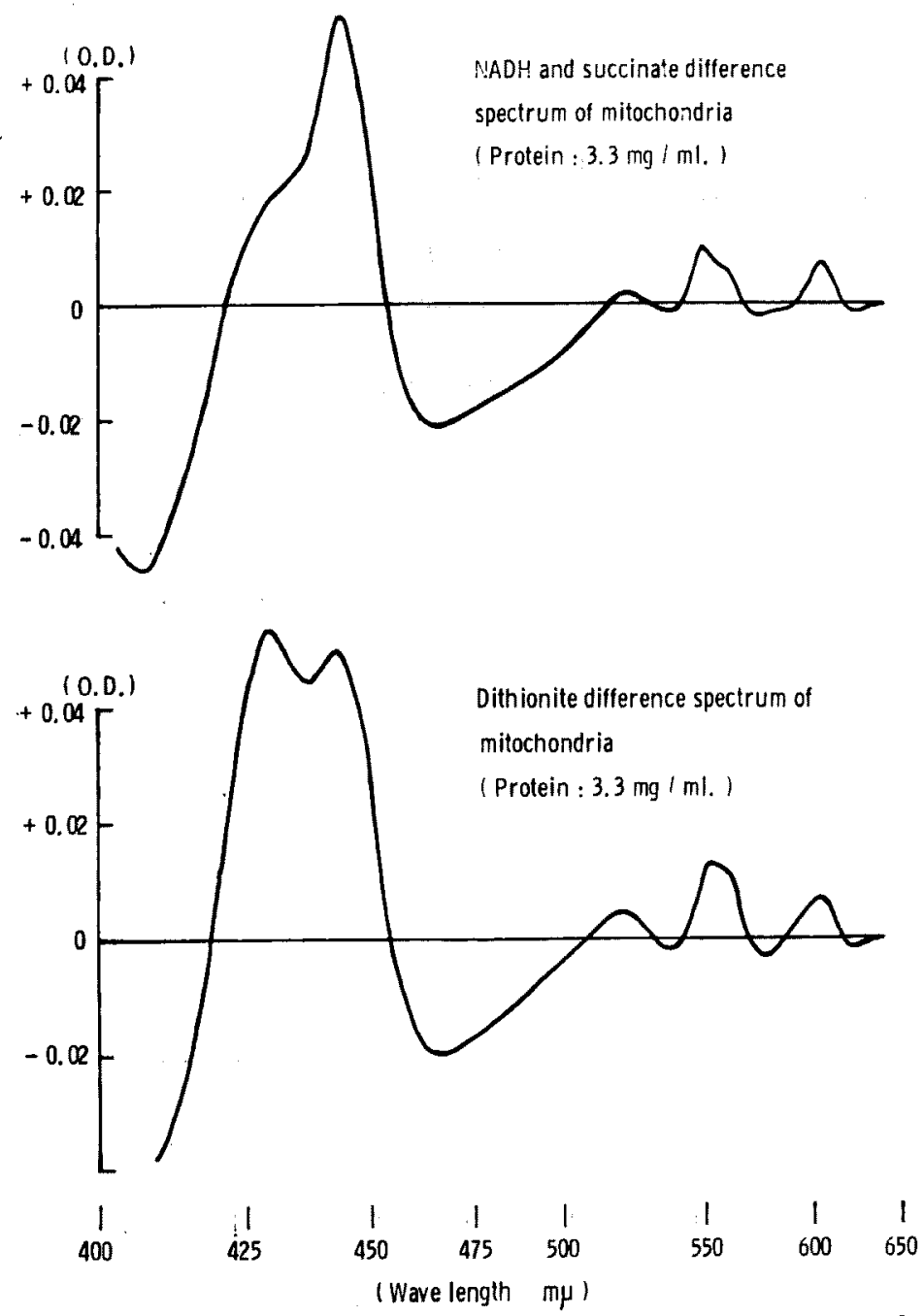

Fig. 4-A. Difference spectra of liver mitochondria in the presence of NADH or dithionite. 

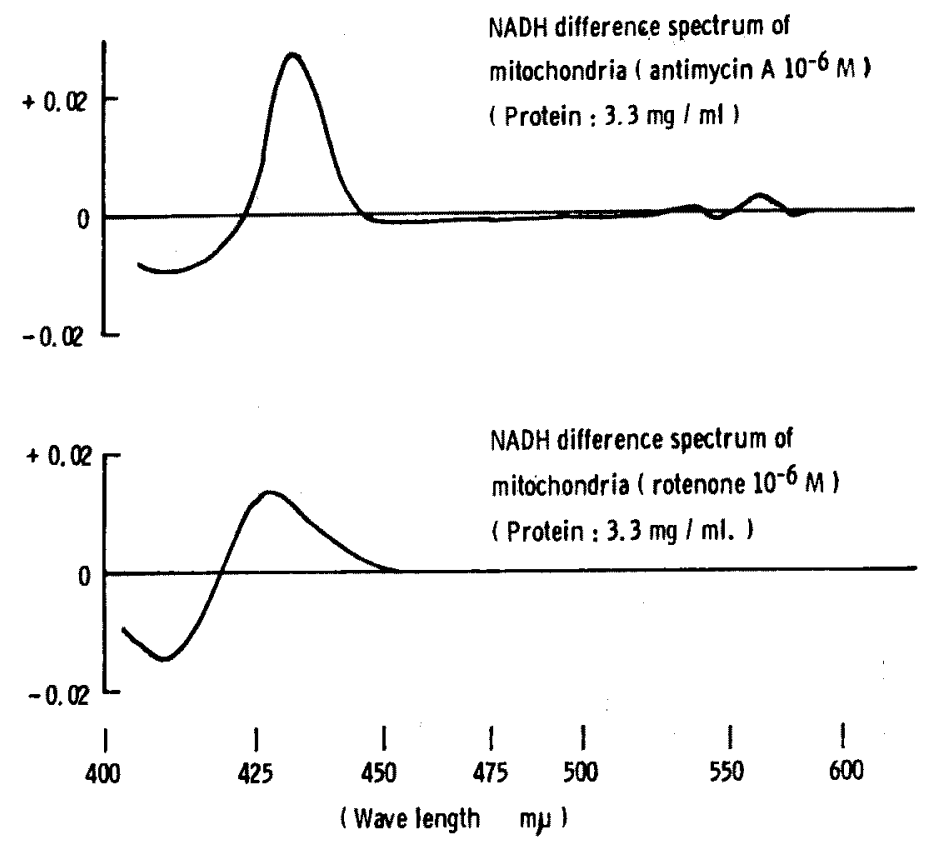

Fig. 4-B. Effects of antimycin A or rotenone on NADH difference spectra of liver mitochondria.
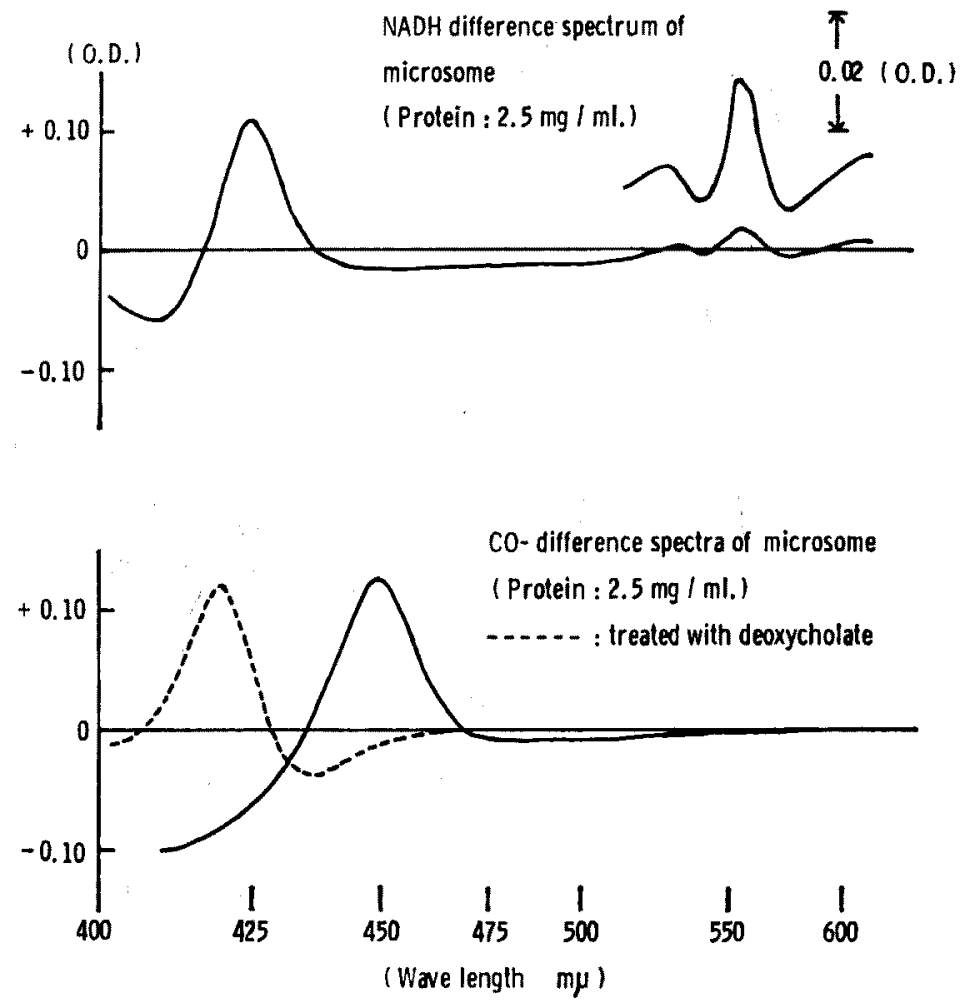

Fig. 5. Difference spectra of liver microsome in the presence of NADH or carbon monoxide. 
(0.0.)
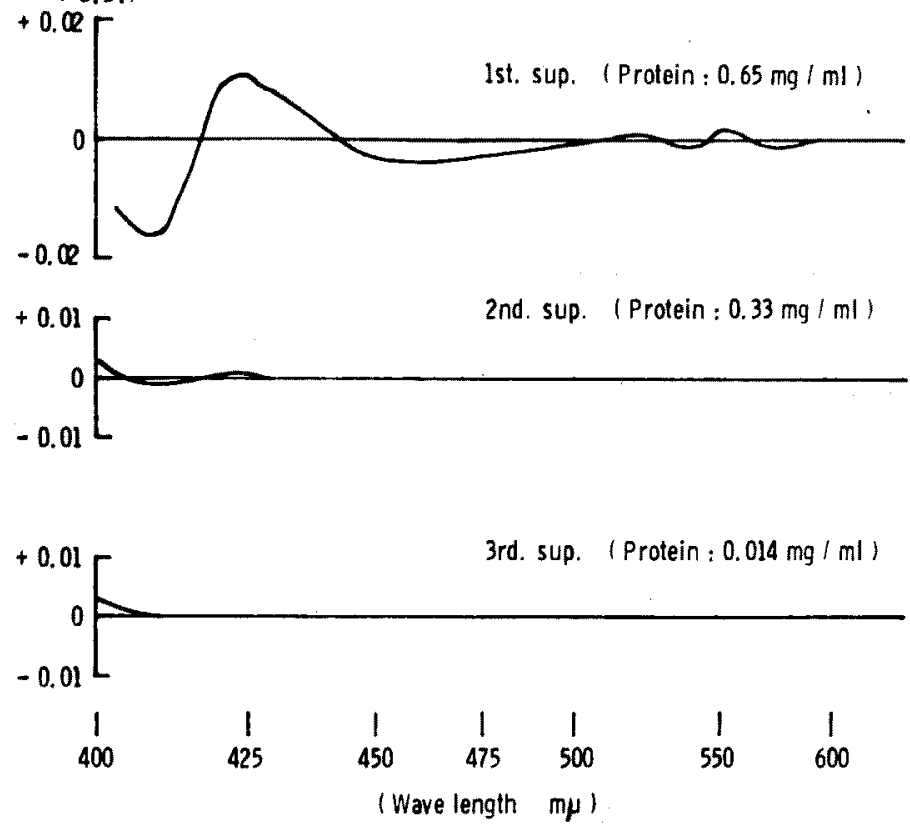

Fig. 6. Dithionite difference spectra of the supernanatants of washed membrane (Each $21 \%, 1.1 \%$ and $0.45 \%$ of total membrane protein was eluted by washing the membrane once, twice and thrice in $0.15 \mathrm{M} \mathrm{KCl}$ solution.)

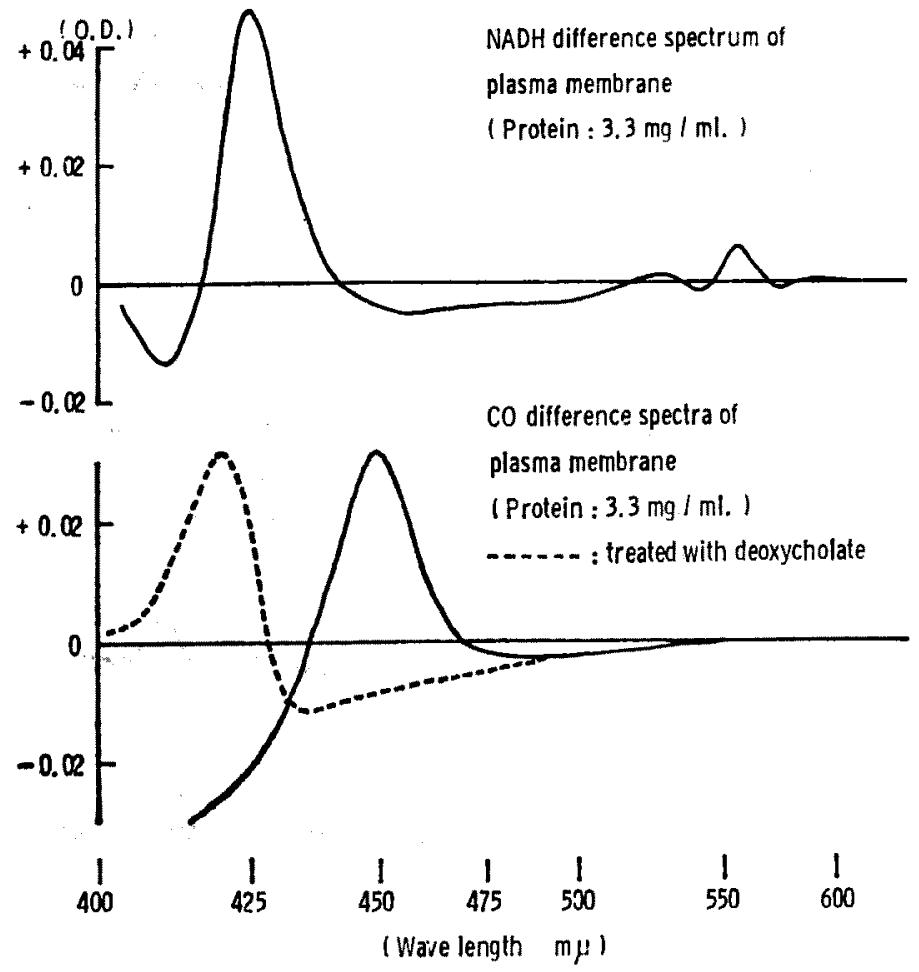

Fig. 7-A. Difference spectra of liver plasma membrane in the presence of NADH or carbon monoxide. 
b）肝細胞膜に怙ける実歌 :

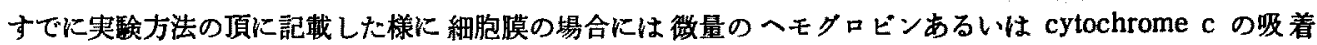
混入が差スペクトルに影響を与えると思われたので，常法により分離した細胞膜を更に 3 回等張の $\mathrm{KCl}$ 溶液で 洗淮した．この糃合，上清中への蛋白の溶解状況並びに dithionite 添加による差スペクトルの詳細は Fig. 6 に示した。すすなわち，これ等の結果から明らかな様に，紐胞膜分画に吸着されたと思われる異種へム蛋白質は一

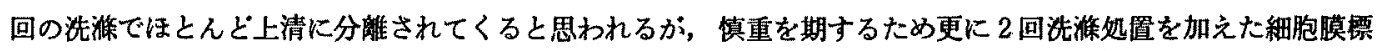
本を用いて実験を進めた。 すなわち Fig. 7A，B に示す通り細胞膜標本に各々 NADH，NADPH 及び dithionite を添加するかあるいは CO 処理を行って見た. 先ず $\mathrm{NADH}$ 添加後には差スペクトルの上に424 $\mathrm{m} \mu$ 及び $556 \mathrm{~m} \mu$ に明かな峰が㑇められたが, この峰は mic. の cytochrome bs のスペクトルに一致する.しかして $\mathrm{CO}$ 差スペクトルでは450 $\mathrm{m} \mu$ にピークが現われるが, この峰は deoxycholate 処理により $420 \mathrm{~m} \mu$ に移動する 事より，細胞膜にも p-450 が存在すると考兄られる。なお， NADH 差スペクトルは mic. の場合と同様 anti-

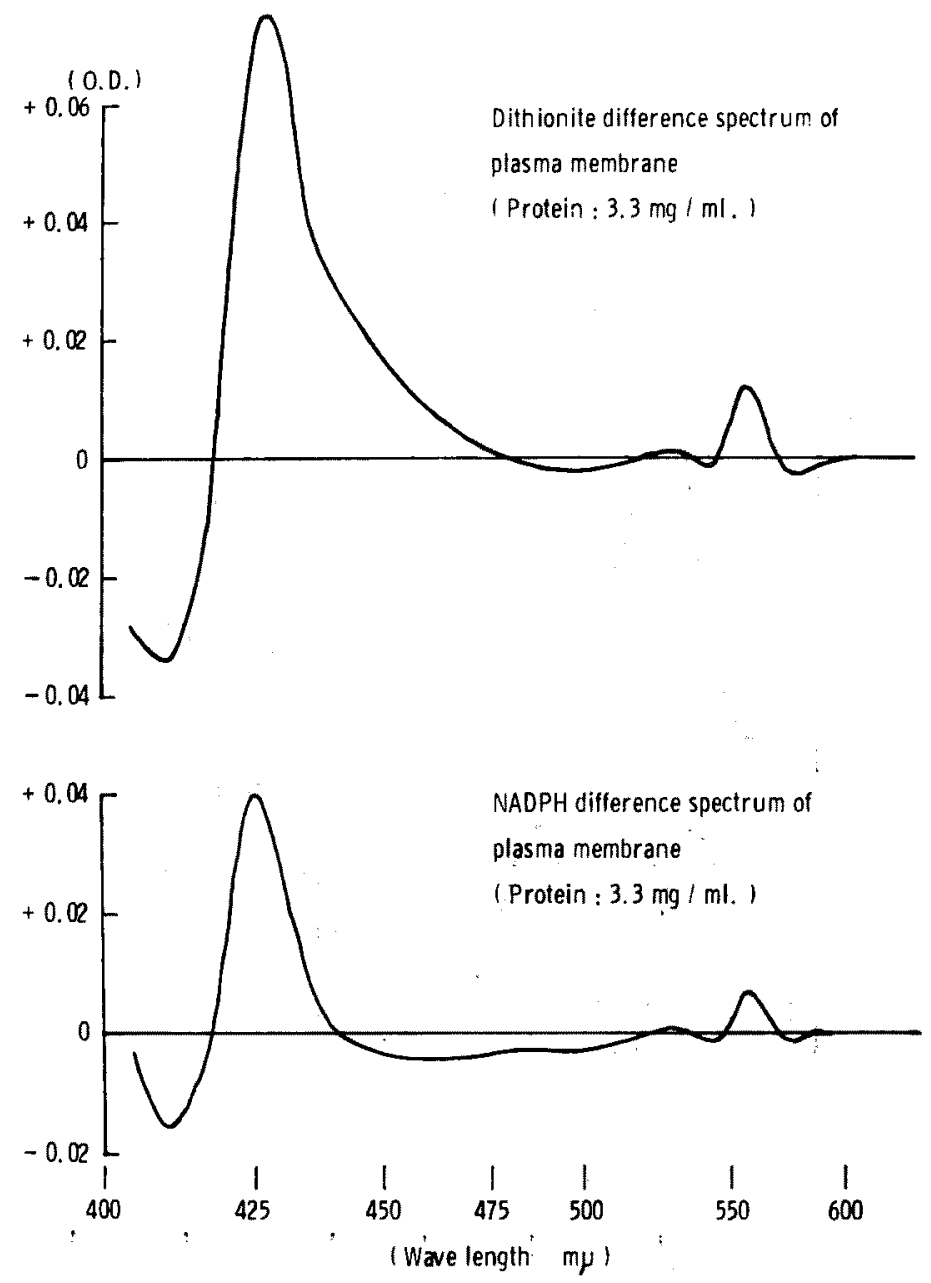

Fig. 7-B. Differenc spectra of liver plasma membrane in the presence of dithionite or:NADPH. 

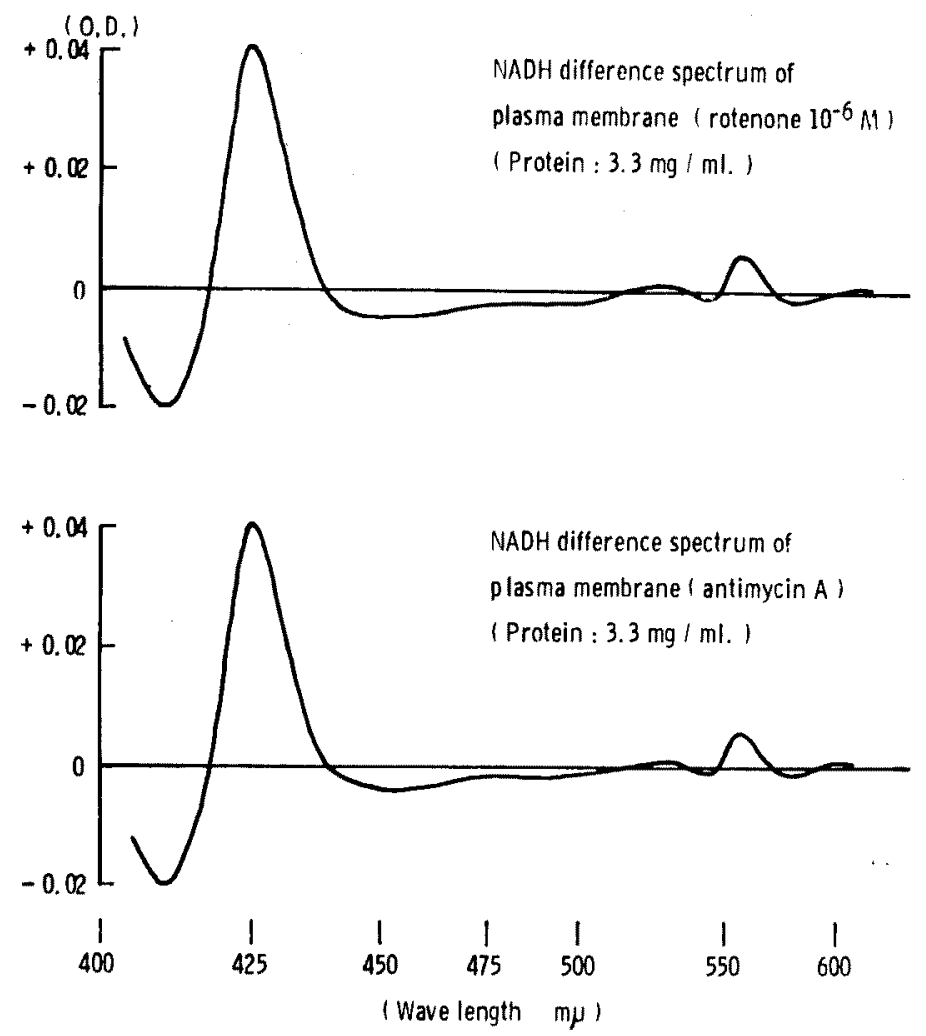

Fig. 7-C. Effect of rotenone or antimycin A on NADH difference spectra of liver plasma membrane.

mycin A あるいは rotenone の添加により影響を受けなかった (Fig. 7C). これらの結果は $\mathrm{CCl}_{4}$ 適用白鼠肝 細胞膜でも同様に認められた。

以上の成続から，旰細胞膜にも mic. 飞存在する 2 種のへム蛋白質 cytochrome $b_{5}$ 及び p-450 が含委れて いる事実が判明したので, 以下 $\mathrm{CCl}_{4}$ 適用に伴ら細胞膜及び mic. のこれらへム蛋白の消長につき梌討を加えた.

[IV] 肝緇胞膜および mic.のへム蛋白合量におよはす $\mathrm{CCl}_{4}$ 適用の影響

正常肝細胞膜では cytochrome $b_{5}$ 及び p-450 の含量は mic. の1/5 1/7 K過ぎない．ところが $\mathrm{CCl}_{4}$ 適 用 $6^{h}$ 後では細胞膜のこれらへム蛋白は共に 2 倍近く增加し, 逆に mic. では両者共半減するに至った. (Table 2)

Table 2. Effects of $\mathrm{CCl}_{4}$ administration on the contents of cytochrome $b_{3}$ and P-450 in plasma membranes or microsomes from rat liver.

\begin{tabular}{c|lcc}
\hline \hline Fraction & Cyt. $b_{5}$ or P-450 & Normal & CCl $_{4}$ \\
\hline \multirow{2}{*}{ Membrane } & Cytochrome $b_{5}$ & $0.093 \pm 0.016$ & $0.229 \pm 0.056$ \\
& P-450 & $0.096 \pm 0.021$ & $0.186 \pm 0.020$ \\
& Cytochrome $b_{5}$ & $0.465 \pm 0.034$ & $0.266 \pm 0.016$ \\
Microsome & P-450 & $0.734 \pm 0.070$ & $0.371 \pm 0.062$
\end{tabular}

Unit: $\mathrm{m} \mu$ moles $/ \mathrm{mg}$ protein

Mean \pm s.d. 
Table 3. Electron transfer from NADH to cytochrome $c$, ferricyanide and cytochrome $b_{3}$ in plasma membranes from normal or $\mathrm{CCl}_{4}$-treated rats.

\begin{tabular}{lcccc}
\hline \hline Treatment & Exp. No. & cyt. c & $\begin{array}{c}\text { (Acceptors) } \\
\text { Fe }\end{array}$ & cyt. b $_{5}$ \\
\hline \multirow{2}{*}{ None } & 1 & 0.151 & 0.72 & 0.050 \\
& 2 & 0.120 & 0.65 & 0.050 \\
& 3 & 0.139 & 0.69 & 0.047 \\
\multirow{2}{*}{$\mathrm{CCl}_{\mathbf{4}}\left(6^{\mathbf{h}}\right)$} & 1 & 0.378 & 1.53 & 0.048 \\
& 2 & 0.398 & 1.45 & 0.062 \\
& 3 & 0.463 & 1.53 & 0.064 \\
& 4 & 0.236 & 0.91 & 0.050
\end{tabular}

Activity; $\mu$ moles of acceptors reduced/mg protein $/ \mathrm{min}$.

この事実は mic. 成分中 cytochrome $b_{5}, p-450$ の相当部分が遊離し細胞膜その他の部分へ移和する可能性 を示唆しており，その結果本来 cytochrome bs の含量が僅少な細胞膜に和いて本へム蛋白の增加を来たすので ，当然 NADH-cyt. c red. 活性の上昇原因となるように思われる.

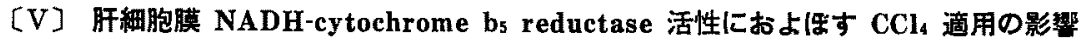

Table 3 には NADH から cytochrome $b_{5}$, cytochrome $c$ 及び ferricyanide への電子伝達活性を比較 し て示した，正常白㼟肝細胞膜では NADH-cytochrome bs reductase 活性は NADH-cyt. c red. 活性の約1/3の 值を示した. しかしながら，CCl、を適用すると NADH-ferricyanide 活性は 2 倍返くに上昇しているにかかわ らず, NADH-cytochrome $b_{5}$ reductase はほとんど上昇しなかった。

\section{総括ならび考按}

白鼠肝細胞膜に括ける NADH-cyt. c red. の酵素化学的性格につき検討を加えたところ，本酵素系は mit.

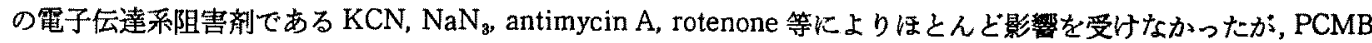
並びに NEM ( SH-阻害剂) により明かな阻害を受け，かつ本阻害はいずれる NADH の共存下では明らかに 進行しない点から SH 基を活性中心とするいわゆる SH 基酔素であるらと思われる. 更に dehydrogenase level 及び reductase level に淤る NADH に対する Km 值を検して見ると両者共 mic. の両酵秦の $\mathrm{Km}$ と一致

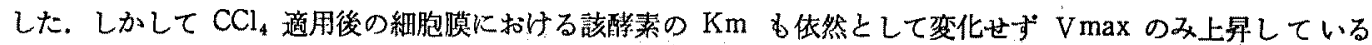

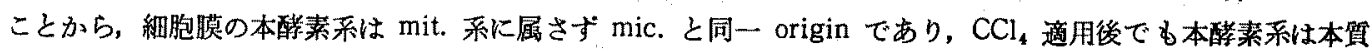
的な改变をこうもらないものと思われる。

他面 mic. のへム蛋白質である cytochrome $b_{5}, p-450$ の同定，定量を細胞膜について訊みたところ，両者 共 mic.に比べすずかではあるが細胞膜に存在する棑が判明したが， $\mathrm{CCl}_{4}$ 適用時には和田等13) る報告している ごとく mic. の cytochrome $b_{5}, \mathrm{p}-450$ 含量は著明な減少をしたのに反し，細胞獏ではこれらへム蛋白含量は約 3 倍に增加した，これらの事実は細胞膜及び mic. の該電子伝達系は同系統のものとした上述の私達の推察を更 に襄付けるものと思われる。

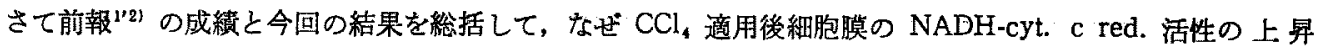
像が発現するかの事由について考察を加えて見ると，NADH-cyt. c red. 系は flavoprotein 系の脱水素 level $と$ cytochrome $b_{5}$ を含む reductase level との複合醉素系であることから ${ }^{2 n}{ }^{2101}, \mathrm{CCl}_{4}$ 適用時の細胞膜 $\mathrm{NADH}$ -ferricyanide dehydrogenase 活性の上昇は flavoprotein の mic. からの移動の結果と考えれば一応の了解が出

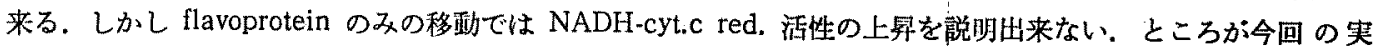
験により NADH-dehydrogenase level のみならず，その cofactor である cytochrome b る 明らかに增加して

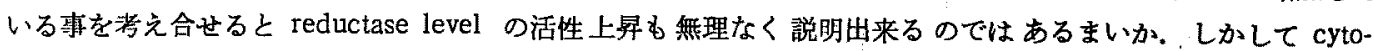
chrome $b_{5}$ の增加機序は同時に mic. の同へム蛋白が相当減少している事から，後者からの移動の可能性 む充 
分予想される。

ここで注目しなければならない事は NADH-dehydrogenase 並びに cytochrome $b_{5}$ の移動量並びに移動形 式である. 通常 mic.においては NADH から cytochrome $b_{5}$ への電子伝達活性は cytochrome $c$ への伝達に 比し，約1/10程度に過ぎないか，本分屏の可溶化に伴い両层達活性法略々同值に近つく事実”から， mic. では cytochrome $b_{5}$ が強固に脱水素酔妻の level で flavoprotein に結合している為, 外因性の cytochrome $b_{5}$ へ の伝達が洋いと言われている，ところが今回の実験で正常肝細胞膜の cytochrome $b_{5}$ の含量は mic. のそれに 比し約1/5であり，また NADH-dehydrogenase 活性も前者は後者の約 $1 / 5$ であったが, NADH-cyt. c red. 活 性の上では約1/10に過きない（第 1 報”，Table 4 参照）のに cytochrome b を添加して還元率を見ると mic. の場合に比し, 外因性 $b_{5}$ への還元は明らか沉高い事実がかかった。この機序については恐らく上述の mic. に 拈计る cytochrome $b_{5}$ の結合状熊と還元率の相互関係から推察し, 正常細胞膜においては, dehydrogenase と bs の結合は mic. のそれに比し弱いのではないかと思かれる。 しかしながら $\mathrm{CCl}_{4}$ 処置後なぜ 外因性の $\mathrm{b}_{5} の$ 寀元が增加しないのかについては mic. から移動する flavoprotein と $b_{5}$ の結合が強いまま膜へ到達するむのと 解すれば矛盾なく説明し得ると思われる。

他面 mic. に扎いては， $\mathrm{CCl}_{4}$ 適用により cytochrome b の上で有意な低下が見られず，また NADH-cyt. c red. 活性の低下が僅が止まるといら事実は, 元来 mic.に 扎いては大過剩に cytochrome $b_{5}$ 存存するかあるいは mic. K拈ける両蛋白の turnover 速度が上昇すると解 すれば, cytochrome $c$ への電子伝達を触媒する cytochrome $b_{5}$ 量は正常 mic.の1/2量であってる充分な触媒能 を示し得ることが想像される. 更に $\mathrm{CCl}$ 、適用に伴い，細胞膜の NADH-cyt. c red. の活性上昇 ${ }^{122}$ 及びp-450含 量の增加が同時に證められる点を考慮すれば, mic. 成分の移動は単に NADH-cyt. c red. 采に止まらず広く電 子伝達系醉素及び補醳素群について巷起される可能性も充分考えられる. しかし，この様な移動がいかなる作用 に基いて惹起されるのかに関しては未だ明らかな結論は下し得ない。

結論

1. 細胞膜 $\mathrm{NADH}$-cyt. $\mathrm{c}$ red. 活性は $\mathrm{KCN}, \mathrm{NaN}_{3}$, antimycin A, rotenone 等によりほとんど有意な阻 害を受けなかったが, PCMB 及び NEM により明らかな阻害を受けた。

2. NADH-cyt. c red. 及び NADH-ferricyanide dehydrogenase の NADH k対する $\mathrm{Km}$ は細胞膜並び 飞 mic. で同一值を示し, かつ $\mathrm{CCl}_{4}$ 適用により上述の相関性に変化がない事から細胞膜の該醉素系は mic. と 同一の origin のものと思放れる.

3. 細胞膜の cytochrome $b_{5}$ 及び p-450 量は，mic.のそれに比し極めて少いが， $\mathrm{CCl}_{4}$ 適用により細胞膜 でこれらのへム蛋白基は的 2 倍に增加し, mic. では逆に半隇した。

4. 細胞膜の NADH-cytochrome $b_{5}$ reductase 活性は NADH-cyt. c red. 活性の約1/3の值を示したが, 本活性値は $\mathrm{CCl}_{4}$ 適用によりほとんと影響を受けなかった。

5. 肝細胞膜の NADH-cyt. c red. 活性が $\mathrm{CCl}_{4}$ 適用後に急滕する機序につき mic. との関連において考 察を加えた. すなわち, mic. の $\mathrm{NADH}$ dehydrogenase 並びに cytochrome $\mathrm{b}_{5} か ゙ \mathrm{CCl}_{4}$ 処置により本分屑を 離れ細胞膜に移行することに由来すると推察される。

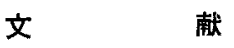

1) 山本博之, 增田康輔, 口井正人, 早野泰造 : 日薬理誌, 68, 142 (1972).

2) 口井正人, 增田康輔, 岡田信行, 山本博之: 日薬理誌, 68, 153 (1972).

3) 口井正人: 日薬理誌，65，592 (1969).

4）萩原文二：蛋白質・核酸・醭素，13，370 (1968).

5) Omura, T. and Sato, R.: J. Biol. Chem., 239, 2370 (1964).

6) 佐藤了, 石本 真, 丹羽 允, 小山次郎：「醭素研究法」（赤堀四郎編） 3 巻, p.173 (1957). 
7) Strittmatter, P.: In "Enzymes" (ed. Boyer, P. D., Lardy, H. and Myrback, K.), Vol. 8, p. 113, Academic Press, New York (1963).

8) Skou, J. C.: Biochem. Biophys. Res. Comm., 10, 79 (1963).

9）広田 和, 大村恒雄, 西林洋子, 佐藤了: 第15回酥素化学シンボシウム予稿集, p.55 (1963).

10）佐藤 了: 蛋白質・核酸・醭素, 10,475 (1965).

11）增田康輔, 口井正人, 岡田信行, 山本博之：日薬理誌，投稿中（第 5 報）.

12）小林茂保，田川邦夫：蛋白質・核酸・蟀素，10，1596 (1965).

13) Omura, T. and Sato, R.: J. Biol. Chem., 237, PC 1375 (1962).

14) Omura, T., Sato, R., Cooper, D. Y., Rosenthal, O. and Estabrook, R. W.: Fed. Proc., 24, 1181 (1965).

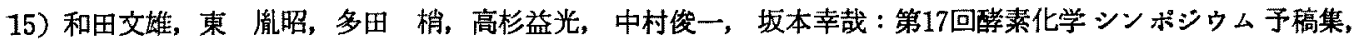
p.242, (1965).

\begin{abstract}
MASUDA Yasusuke, KUCHII Masato and YAMAMOTO Hiroyuki. Department of Pharmacology, Wakayama Medical College, Wakayama. Studies on the cell membrane (IV) Enzymatic characterization of the $N A D H$-cytochrome c reductase in cell membrane from nor mal and $\mathrm{CCl}_{4}$-treated rat liver. Folia pharmacol. japon. 68, 167 178 (1972) Tables 3, Illus. 10.

1) NADH-cytochrome $c$ reductase activity in membrane was inhibited by p-chlo romercuric benzoate and $\mathrm{N}$-ethylmaleimide, but not by $\mathrm{KCN}, \mathrm{NaN}_{3}$, Antimycin $\mathrm{A}$ or rotenone.

2) Both NADH-cytochrome $c$ reductase and NADH-ferricyanide dehydrogenase located in the membrane and microsome showed the same $\mathrm{Km}$ value respectively. These $\mathrm{Km}$ values were retained unchanged even in case of $\mathrm{CCl}_{4}$ treatment in vivo.

3) Membrane also contained cytochrome $b_{5}$ and P-450, of which contents were much lower than those in microsome. $\mathrm{CCl}_{4}$, however, resulted in an increase of these heme proteins to twice in membrane, but a decrease to half in microsome.

4) NADH-cytochrome $b_{5}$ reductase activity was only one third of NADH-cytochrome $c$ reductase activity in membrane irrespective of $\mathrm{CCl}_{4}$ administration in vivo.

5) It is proposed that $\mathrm{NADH}$-cytochrome $c$ reductase in membrane orignates from microsome, but not from mitochondria, and that increase of enzyme activity after $\mathrm{CCl}_{*}$ administration may be caused by migration of heme- and flavo-proteins from endoplasmic reticulum to plasma membranes of liver celis in vivo.
\end{abstract}

